PiJIES: Pedagogik Journal of Islamic Elementary School April 2018, Vol.1, No.1, hal. 37-46

ISSN(P): 2356-1483; ISSN(E): 2615-3904

(c) 2018 PGMI IAIN Palopo. http:// ejournal-iainpalopo.ac.id/ PiJIES

\title{
KETERAMPILAN MEMBACA NYARING DENGAN MENGGUNAKAN MEDIA KARTU KATA
}

\author{
Fitriani \\ Institut Agama Islam Negeri Palopo \\ Jl. Agatis Balandai Kota Palopo, 91914 \\ E-mail: fitrianisaipullah@gmail.com
}

\begin{abstract}
This study aims to determine the increase in reading literacy skills by using word card media for grade II students of SDN 55 Padang Lambe, Wara Barat District, Palopo City. This research is a classroom action research (PTK) and the one acting as the subject in this study was the second grade students of SDN 55 Padang Lambe, Wara Barat Sub-district, Palopo City, totaling 15 people. Data collection techniques used through observation, tests and documentation methods with planning, implementation, observation and reflection procedures. This research was conducted in two cycles. Data processing and analysis techniques used are quantitative descriptive techniques. The results of this study using word cardmedia in increasing loud reading skills have increased, which can be seen in the average pre-cycle 67.66 with $33.33 \%$ completeness, in cycle I the average value is 72.6 with $80 \%$ completeness and in cycle II the average value was 83.46 with $100 \%$ completeness. Thus the average value of students has reached the KKM.
\end{abstract}

Keywords: Reading Skill, Media Word Card

\begin{abstract}
Abstrak
Penelitian ini bertujuan untuk mengetahui peningkatan keterampilan membaca nyaring dengan menggunakan media kartu kata pada siswa kelas II SDN 55 Padang Lambe Kecamatan Wara Barat Kota Palopo. Penelitian ini merupakan penelitian tindakan kelas (PTK) dan yang bertindak sebagai subjek dalam penelitian ini adalah siswa kelas II SDN 55 Padang Lambe Kecamatan Wara Barat Kota Palopo yang berjumlah 15 orang.Teknik pengumpulan data yang digunakan melalui metode observasi, tes dan dokumentasi dengan prosedur perencanaan, pelaksanaan, pengamatan dan refleksi. Penelitian ini dilakukan sebanyak dua siklus.Teknik pengolahan dan analisis data yang digunakan yaitu teknik deskriptif kuantitatif. Hasil peneltian ini dengan menggunakan media kartu kata dalam peningkatan keterampilan membaca nyaring mengalami peningkatan, yaitu dapat dilihat pada nilai rata-rata prasiklus 67,66 dengan ketuntasan 33,33\%, pada siklus I nilai rata-rata adalah 72,6 dengan ketuntasan 80\% dan pada siklus II nilai rata-rata adalah 83,46 dengan ketuntasan 100\%. Dengan demikian nilai rata-rata siswa sudah mencapai KKM.
\end{abstract}

Kata Kunci,: Keterampilan Membaca Nyaring, Media Kartu Kata

\section{PENDAHULUAN}

Pendidikan ialah adanya pendidik dengan peserta didik dan terjadi suatu hubungan timbal balik atau terjadinya interaksi antara pesrta didik dan pendidik di dalam kelas atau dimanapun. Terjadinya proses pembelajaran

Vol 1, No.1, April 2018 


\section{8 | Fitriani}

dalam suatu pendidikan guna untuk mencapai suatu tujuan pendidikan misalnya menciptakan peserta didik yang cerdas, berakhlakul qorimah, berguna bagi agama, bangsa dan Negara. Di dalam hubungan pendidikan memiliki fungsi pendidikan seperti; dapat membantu peserta didik dalam mengembangkan semua potensi yang dimiliki, baik dari segi sikap, ilmu pengetahuan, keterampilan dan sosial. Menurut Nana Syaodih Sukmadinata (2015: 4) bahwa adanya proses pendidikan secara langsung dimulai dari lingkungan keluarga, lingkungan sekolah dan lingkungan masyarakat. Dalam lingkungan keluarga yang menjadi pendidik yaitu anggota keluarga khususnya ayah dan ibu karena merekalah yang berperan sangat penting dalam memberikan pengajaran yang baik. Kemudian pengajaran yang diberikan oleh guru di sekolah dan pengajaran yang di berikan dalam suatu masyarakat terhadap anak maupun remaja dan orang dewasa. Seperti yang dikatakan oleh H.Suryosubroto (1990: 31) bahwa lingkungan sangat memberikan pengaruh besar terhadap peserta didik.

Hal ini terdapat dalam pasal 1 Undang-undang No. 20/2003 tentang sistem pendidikan nasional bahwa pendidikan adalah usaha sadar dan terencana untuk menciptakan lingkungan dan proses pembelajaran agar siswa mampu mengembangkan potensinya untuk memperoleh kekuatan spritual keagamaan, mengembangkan kendali diri, kepribadian, kecerdasan, akhlak mulia dan keterampilan yang dibutuhkan oleh dirinya, masyarakat, bangsa dan Negara ( Suwarsih Madya 2013: 10). Belajar membaca adalah mengembangkan ilmu pengetahuan serta menerapkan lambang-lambang tulisan dengan makna, sehingga terjadi suatu perubahan pada diri anak, dari hal tersebut maka terjadi suatu rangsangan agar dapat memudahkan siswa dalam belajar membaca dengan membaca diperlukan suatu strategi $(\mathrm{M}, \mathrm{F}$ Baradja 1990: 132). Hal ini sesuai dengan pendapat Syamsu (2017: 120) bahwa penerapan metode, gaya mengajar dan strategi yang bervariasi akan memberi kesan menarik pada peserta didik. Penerapan pengajaran dan pelatihan yang tepat dapat menstimulus otak siswa untuk bekerja secara optimal sehingga usaha pencapaian tujuan pembelajaran berdasarkan kurikulum akan optimal pula (Rustan, 2017). Secara psikologis peserta didik akan patuh dan merasa senang terhadap kegiatan pembelajaran yang sedang berlangsung. Menurut E. Mulyasa (2008:106) mengatakan bahwa guru dapat memberikan dukungan dalam mengembangkan kepercayaan diri pada siswa agar mereka tidak merasa takut, malu atau kurang percaya diri. Kemudian

memberikan kesempatan kepada siswa dalam berbicara, guru mengawasi siswa secara bebas dan tidak terlalu menekan. Pemberian persuasi verbal, membangkitkan pengalaman prestasi dan perbaikan kondisi psikologis serta fisiologis dapat menjadi pembangkit siswa dalam menyelesaikan tugas (Thaha \& Rustan, 2017). Hal ini dikatakan juga Slameto (2013: 27-28) bahwa

\section{PiJIES: Pedagogik Journal of Islamic Elementary School}


seharusnya siswa berusaha ikut berpartisipasi agar dapat menumbuhkan perhatian, mendapatkan bimbingan dan berinterkasi dengan lingkungan untuk mencapai suatu tujuan. Dalam pembelajaran Bahasa Indonesia membaca nyaring bukan hanya sekedar membaca saja namun memiliki ciriciri suprasegmental diantaranya; tekanan, jedah, intonasi, durasi dan nada (Masnur Muslich 2011: 112). Menurut Nina Sofiani (2014: 258) pembelajaran membaca nyaring yang dilakukan di sekolah dasar agar siswa dapat memperoleh pengajaran membaca nyaring sesuai dengan aturan kaidah Bahasa Indonesia.

Di sekolah guru seharusnya dituntut dalam meningkatkan keterampilan membaca, dan menulis dengan menggunakan berbagai cara yang dapat menimbulkan semangat siswa. Sehingga keterampilan membaca dan menulis mereka akan lebih meningkat. Dengan demikian perlu dilakukan penelitian tindakan kelas dengan menggunakan media kartu kata dalam membaca nyaring di kelas II SDN 55 Padang Lambe Kecamatan Wara Barat Kota Palopo.

Peserta didik akan tertarik jika pembelajaran yang diberikan oleh guru dengan cara yang menarik pula sehingga siswa akan memperhatikan pembelajaran tersebut selama proses pembelajaran berlangsung namun, begitupun sebaliknya (Kartini Kartono 1985: 3). Oleh sebab itu guru seharusnya memberikan pengajaran yang dapat membuat siswa tertarik dalam mengikuti pelajaran terutama dalam proses pembelajaran keterampilan membaca nyaring.

Keterampilan membaca nyaring ialah keterampilan yang sangat penting diajarkan kepada siswa dan memiliki seluk beluk yang harus diperhatikan misalnya memperhatikan kelancaran, intonasi, kejelasan, pelafalan dan lainlain sebagainya. Untuk itu kita perlu menciptakan cara untuk membangkitkan semangat siswa. Hal ini sesuai yang dikatakan oleh S. Nasution (2004: 82) bahwa bangkitkan suatu kebutuhan (kebutuhan untuk menghargai keindahan, untuk mendapat penghargaan serta, hubungkan dengan pengalaman yang lampau.

Adapun hal-hal yang perlu dilakukan guru menurut Nuni Yusvavera Syatra (2013:98-99) ialah ucapkanlah kata yang lembut, sopan dan tidak berkata kasar, tunjukkanlah sikap yang baik, sopan pada saat memberikan jawaban terhadap siswa, yaitu memberikan pujian terhadap siswa, memotivasi siswa dalam belajar, murah senyum, tidak menenggangkan, memberikan arahan terhadap siswa dalam menjawab pertanyaan dengan benar, memberikan sanjungan dan penghargaan, tidak terlalu cepat bicara, memberikan giliran pada setiap siswa dalam menjawab pertanyaan atau 


\section{0 | Fitriani}

memberikan pertanyaan. Dengan adanya kegiatan tersebut maka suasana dalam proses belajar dapat hidup dan menyenangkan. Menurut Oemar Hamalik (1993: 27) menyatakan bahwa belajar ialah terjadinya suatu perubahan dalam diri seseorang baik dari segi sikap, pengetahuan, keterampilan dan lain-lain. Terjadinya perubahan pada diri seseorang melalui proses belajar dan mendapatkan suatu pengalaman atau mengalami suatu perubahan Tingkah laku sama halnya dengan sikap seperti yang dikatakan oleh Wirawan Sarwono (1997: 201) bahwa manusia dapat mempunyai bermacam-macam sikap terhadap bermacam-macam hal, sikap dapat dikatakan dalam tiga hal yaitu perasaan, perilaku dan penilaian.

Melakukan pembelajaran ada empat hal yang biasa dilakukan oleh guru yang biasa disebut dengan $4 \mathrm{M}$ yang dikemukakan oleh Dewi Utami Fausiah (2003:8-9) yaitu menyenangkan, mengasyikkan, mencerdaskan dan menguatkan. Menurut Zulela (2012: 3) mengatakan Bahasa merupakan hasil budaya yang hidup dan berkembang dan harus dipelajari. Bahasa Indonesia sebagai suatu bahasa yang berkembang dan mempunyai banyak ragam masing-masing berfungsi dalam komunikasi (Rustan, 2016). Bahasa merupakan suatu alat komunikasi yang digunakan dalam berinteraksi dengan orang lain. Sehubungan dengan hal tersebut Sukirman Nurdjan dan Edhy Rustan ( 2010: 13) menyatakan bahwa "tanpa Bahasa pengembangan kebudayaan, ilmu pengetahuan dan teknologi akan mengalami hambatan."Sesuai dengan pendapat Moh.Yamin (2009: 226) dalam proses belajar mengajar guru harus mampu menyampaikan pesan dengan bahasa sederhana agar siswa mudah memahami apa yang disampaikannya, sebab bahasa peserta didik berbeda dengan bahasa pendidik / guru. Sehingga dalam bahasa ada empat aspek yang perlu diketahui yaitu aspek menulis, mendengarkan, membaca, dan berbicara. Salah satunya yang dipelajari ialah aspek membaca. Membaca merupakan suatu kegiatan yang dilakukan untuk memperoleh pesan.

Keterampilan Membaca nyaring ialah kegiatan membaca yang dilakukan dengan bersuara serta memperhatikan pengucapan, intonasi, kelancaran serta kenyaringan dalam membaca nyaring. Menurut Henry Guntur Tarigan (1979: 22) membaca nyaring ialah kegiatan yang dilakukan oleh guru,murid ataupun dengan orang lain dalam memahami isi bacaan tersebut. Dalam membaca nyaring khususnya dikelas dua ada beberapa hal yang perlu diperhatikan yaitu pengucapan yang tepat, frase, intonasi, pelafalan, kelancaran, kenyaringan serta menguasai tanda-tanda baca sederhana seperti tanda titik(.), koma(,), tanda tanya(?) dan tanda seru(!). Berhubungan dengan hal tersebut maka Farida Rahim (2008: 11) mengemukakan beberapa tujuan dalam membaca nyaring yaitu, senang, 
menyempurnakan dalam membaca nyaring, mempunyai strategi tertentu, memperbaharui pengetahuannya tentang suatu topik, menghubungkan pengalaman baru dengan pengalaman sebelumnya.

Peningkatan keterampilan membaca nyaring adalah hal yang sangat penting yang perlu dilakukan dalam menyelesaikan permasalahan yang berkaitan dengan membaca nyaring, salah satu langkah yang diambil peneliti dalam menyelesaikan permasalahan ini ialah dengan menggunakan media pembelajaran yaitu media kartu kata yang bervariasi, berbentuk persegi, setiap kartu berisi kata yang memiliki arti. Manfaat Media kartu kata dalam pembelajaran Bahasa Indonesia yaitu memotivasi siswa dalam mengikuti pelajaran, siswa tidak merasa bosan atau jenuh dalam belajar, membuat siswa terlibat secara langsung dan dapat menarik perhatian siswa dalam mengikuti pelajaran. Sehubungan dengan pendapat Syaiful Bahri Djamarah bahwa penggunaan media adalah untuk mengurangi verbalisme agar anak didik mudah memahami pelajaran yang disajikan. Sehubungan dengan pendapat Ashar Arsyad (2007: 24-25) menyatakan ada beberapa fungsi media dalam pembelajaran membaca yaitu, memberikan motivasi kepada siswa dalam membaca, dapat menarik perhatian siswa, memotivasi siswa agar mau membaca, menarik perhatian siswa, dapat memudahkan guru dan siswa dalam melakukan pembelajaran sesuai dengan materi yang diajarkan.

Melalui penggunaan media kartu kata dalam pembelajaran Bahasa Indonesia siswa dapat memiliki pengalaman konkrit dan dapat menarik perhatian siswa serta memberikan keterampilan siswa dalam membaca nyaring, sehingga mendapatkan hasil yang diharapkan. Penggunaan media ini menggunakan kertas yang berwarna-warni agar siswa dapat tertarik dan termotivasi dalam mengikuti pembelajaran. Kemudian setiap kertas ditulis satu kata yang memiliki makna atau arti contohnya:
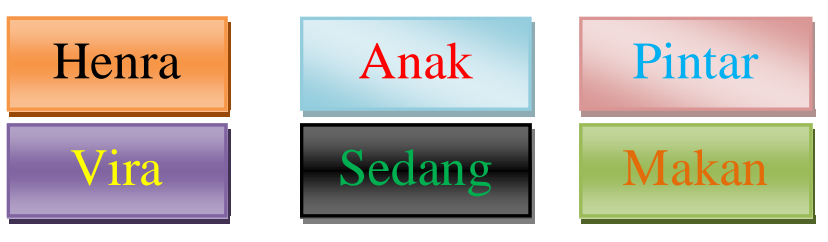

\section{METODE}

Penelitian ini merupakan penelitian tindakan kelas (PTK) yaitu penelitian yang terjadi berdasarkan permasalah yang terjadi di dalam kelas. Hal ini dapat dilihat secara langsung pada kegiatan aktivitas siswa selama proses pembelajaran berlangsung di dalam kelas. Pendekatan yang digunakan pada penelitian ini ialah pendekatan psikologi lebih melihat pada kreativitas siswa. Objek yang digunakan dalam penelitian ini ialah 


\section{2 | Fitriani}

keterampilan siswa dalam membaca nyaring pada mata pelajaran Bahasa Indonesia. Dalam penelitian ini peneliti menggunakan model penelitian tindakan kelas yang diterapkan oleh Kurt Lewin. Dimana penelitian ini terdiri dari empat tahap yang digunakan yaitu yang pertama perencanaan, kedua pelaksanaan, ketiga observasi, dan keempat refleksi (H. Wina Sanjaya, M.Pd 2009: 50).

Lokasi penelitian ini dilaksanakan di SDN 55 Padang Lambe Kecamatan Wara Barat Kota Palopo. Dalam penelitian ini peneliti menggunakan jenis data penelitian yaitu (a) Data primer adalah data yang diperoleh langsung dari subjek penelitian yaitu data hasil belajar siswa yang diperoleh melalui tes, data aktivitas guru yang diperoleh melalui observasi akivitas guru dan data aktivitas siswa,(b) Data sekunder adalah data yang diperoleh lewat pihak lain, tidak langsung diperoleh dari subjek penelitian, misalnya profil sekolah, data guru, data siswa serta sarana dan prasarana yang ada di sekolah tersebut yang dibutuhkan dalam kelengkapan penelitian. Adapun subjek dalam penelitian ini adalah siswa kelas II yang berjumlah 15 siswa SDN 55 Padang Lambe Kecamatan Wara Barat Kota Palopo.

Teknik yang digunakan dalam pengumpulan data ini ialah observasi, tes dan dokumentasi. Pengolahan data pada penelitian ini dilakukan setelah semua data yang diperoleh telah terkumpul. Kemudian dianalisis secara kuantitatif dan kualitatif. Untuk analisis secara kuantitatif digunakan analisis secara statistik deskriptif yaitu skor rata-rata dan persentase. Sedangkana analisis kualitatif dilakukan terhadap data yang diperoleh melalui observasi aktivitas belajar siswa dan guru dalam penggunaan media kartu kata dengan peningkatan keterampilan siswa dalam membaca nyaring.

Analisis ini dihitung dengan menggunakan statistik sederhana dengan mencari rerata menjumlahkan semua nilai siswa yang ada kemudian dibagi dengan jumlah siswa selanjutnya dikali seratus, kemudian diperoleh nila rata-rata hasil penelitian tersebut selanjutnya diklasifikasikan kedalam bentuk penskoran siswa yang terdiri dari lima kategori yaitu kategori sangat baik 80-100, kategori baik 70-79, kategori cukup 60-69, kategori gagal 0-49 ( Muhibin Syah 2009: 223). Siswa dikatakan tuntas apabila telah memenuhi nilai KKM (kriteria ketuntasan minimum) yaitu 70.

\section{HASIL PENELITIAN}

Setelah peneliti menggunakan media kartu kata dalam membaca nyaring di kelas II SDN 55 Padang Lambe Kecamatan Wara Barat Kota Palopo, dapat diketahui bahwa keterampilan siswa dalam membaca nyaring mengalami peningkatan. Sebab penggunaan media pembelajaran yang bervariasi membuat siswa lebih aktif, lebih semangat dalam mengikuti kegiatan pembelajaran. Sehingga tujuan pembelajaran dapat tercapai dengan baik. Hal ini dapat dilihat 
dari nilai tes prasiklus, siklus I, dan siklus II. Dapat dilihat pada diagram sebagai berikut:

\section{Diagram Peningkatan Keterampilan Membaca Nyaring Pada Prasiklus,} Siklus I, Dan Siklus II

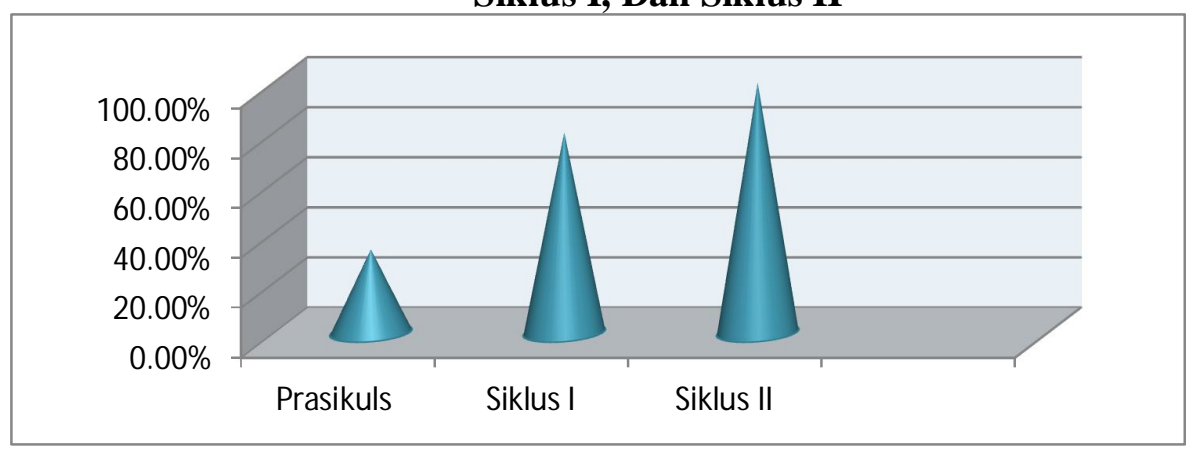

Berdasarkan diagram di atas bahwa terjadi peningkatan nilai tes evaluasi pada setiap siklus yang menandakan bahwa nilai keterampilan membaca nyaring siswa meningkat mulai dari prasiklus dengan nilai rata-rata 67, 66 dengan persentase 33, 33\% kemudian siklus I dengan nilai rata-rata 72, 6 dengan persentase $80 \%$ dan pada siklus II dengan nilai rata-rata 83, 46 dengan persentase $100 \%$. Dengan demikian penggunaan media kartu kata dapat mengalami peningkatan keterampilan membaca nyaring pada siswa kelas II SDN 55 Padang Lambe Kecamatan Wara Barat Kota Palopo.

\section{PEMBAHASAN}

Seperti yang telah dikemukakan pada bagian pendahuluan bahwa, penelitian ini bertujuan pada peningkatan keterampilan membaca nyaring dengan menggunakan media kartu kata pada siswa kelas II SDN 55 Padang Lambe Kecamatan Wara Barat Kota Palopo. Berdasarkan rumusan masalah penelitian, hasil penelitian ini ditujukan untuk mengetahui proses pelaksanaan membaca nyaring dengan menggunakan media kartu kata dan peningkatan keterampilan membaca nyaring pada siswa kelas II SDN 55 Padang Lambe Kecamatan Wara Barat Kota Palopo. Berdasarkan rumusan masalah tersebut maka dapat diketahui bahwa Penelitian ini merupakan penelitian tindakan kelas yang terdiri dari dua siklus. Setiap siklus terdiri dari empat kali pertemuan dimana tiga kali pertemuan dilakukan sebagai proses pembelajaran dan satu kali pertemuan dilakukan evaluasi untuk mengetahui keterampilan siswa dengan proses pembelajaran guru menunjukkan kartu kata kepada siswa guna menumbuhkan motivasi siswa kemudian guru memberikan contoh membaca nyaring setelah itu siswa menirukan bacaan yang di contohkan oleh guru, selanjutnya siswa dibagi menjadi tiga kelompok. Setiap kelompok mendapatkan beberapa kartu kata kemudian mereka menyusun kartu kata menjadi sebuah kalimat tersebut lalu 


\section{4 | Fitriani}

menempelkan di papan yang sudah disiapkan. Setelah itu siswa secara berkelompok membacakan beberapa kalimat yang telah di rangkainya di papan, selanjutnya secara individu membacakan kalimat tersebut dengan suara nyaring. Selain itu selama proses pembelajaran, dilakukan observasi untuk mengetahui aktivitas guru dan siswa.

Dengan penggunaan media kartu kata yang berwarna-warni Selama proses pembelajaran maka dapat diketahui hasil peningkatan siswa dalam membaca nyaring, dapat dilihat pada nilai rata-rata yang diperoleh pada prasiklus yaitu 67,66 siklus I yaitu 72,6 dan mengalami peningkatan pada siklus II yaitu 83,46 Dengan demikian hasil penelitian dengan menggunakan media kartu kata menunjukkan adanya peningkatan keterampilan membaca nyaring pada siswa kelas II dapat diketahui apabila diklasifikasikan kedalam lima kategori yang terdiri dari 15 siswa yang menjadi subjek penelitian, tidak ada yang mendapat nilai kategori gagal, nilai kategori cukup, nilai kategori kurang, 3 siswa yang mendapat kategori baik yaitu 20\% dan 12 siswa yang mendapat kategori sangat baik yaitu $80 \%$.

\section{PENUTUP}

Berdasarkan hasil penelitian ini maka peneliti dapat menyimpulkan sebagai berikut

Pada proses pelaksanaan membaca nyaring dengan menggunakan media kartu kata pada siswa kelas II SDN 55 Padang Lambe Kecamatan Wara Barat Kota Palopo yang terdiri dari dua siklus. Setiap siklus terdiri dari empat kali pertemuan dimana tiga kali pertemuan dilakukan sebagai proses pembelajaran dan satu kali pertemuan dilakukan evaluasi. Guru menunjukkan kartu kata kepada siswa guna menumbuhkan motivasi siswa kemudian guru memberikan contoh membaca nyaring setelah itu siswa menirukan bacaan yang di contohkan oleh guru, selanjutnya siswa dibagi menjadi tiga kelompok. Setiap kelompok mendapatkan beberapa kartu kata kemudian mereka menyusun kartu kata menjadi sebuah kalimat, lalu menempelkan di papan yang sudah disiapkan. Setelah itu siswa secara berkelompok membacakan beberapa kalimat yang telah di rangkainya di papan, selanjutnya secara individu membacakan kalimat tersebut dengan suara nyaring. Selain itu selama proses pembelajaran, dilakukan observasi untuk mengetahui aktivitas guru dan siswa.

Dengan penggunaan media kartu kata yang berwarna-warni Selama proses pembelajaran maka dapat diketahui hasil peningkatan siswa dalam membaca nyaring, dapat dilihat pada nilai rata-rata yang diperoleh pada prasiklus yaitu 67,66 dengan persentase ketuntasan 33.33\%, siklus I yaitu 72,6 dengan ketuntasan 80\% dan mengalami peningkatan pada siklus II yaitu 
83,46 dengan ketuntasan 100\%. Dengan demikian penggunaan media kartu kata dapat mengalami peningkatan keterampilan membaca nyaring pada siswa kelas II SDN 55 Padang Lambe Kecamatan Wara Barat Kota Palopo.

\section{DAFTAR PUSTAKA}

Arsyad Ashar, Media Pembelajaran. 2007. Jakarta: Grafindo Persada.

Baradja. M. F. Kapita Selekta Pengajaran Bahasa. 1990. Malang: IKIP Malang

Djamarah Syaiful Bahri. 1994. Prestasi Belajar dan Kompetensi Guru. Jakarta: Usaha Nasional.

Hamalik Oemar. 1993. Pengembangan Kurikulum Lembaga Pendidikan dan Pelatihan. Bandung: Trigenda Karya.

Kartono kartini.1985. Bimbingan Belajar di SMA dan Perguruan Tinggi. Jakarta: Rajawali.

Madya Suwarsih. 2013. Metodologi Pengajaran Bahasa. Yogyakarta: Uny Pres.

Mulyasa E. 2008. Kurikulum Berbasis Kompetensi. Bandung: PT Remaja Rosdakarya.

Muslich Masnur. 2011. Fonologi Bahasa Indonesia. Jakarta : PT Bumi Aksara.

Nasution S. 2004. Didakti Asas-asas Mengajar. Jakarta: Bumi Aksara.

Nurdjan S., \& Rustan E. (2010). Kunci Sukses Berbahasa Indonesia. Palopo: Lembaga Penerbitan STAIN (LPS) STAIN Palopo.

Sofiani Nina, Peningkatan Kemampuan Membaca Nyaring Melalui Metode Modeling pada Siswa Kelas VI SD Negeri Lambelu Kec. Bumi Raya Kab. Morowali”Jurnal, Kreatif Tadulako Online, Vol 2 No.4 Tahun 2014.

Rahim Farida. 2008. Pengajaran Membaca di Sekolah Dasar. Jakarta: PT, Bumi Aksara.

Rustan, E. (2016). Analisis Penggunaan Bahasa Indonesia Laras Hukum Pada Putusan Perkara Ekonomi Syariah Pengadilan Agama Makassar. Al Amwal, I(2), 166-176.

Rustan, E. (2017). Learning Creative Writing Model Based on Neurolinguistic Programming. International Journal of Language Education and Culture Review, 3(2), 13-29. https:/ / doi.org/ 10.21009/ IJLECR.032.02

Sukmadinata Nana Syaodih. 2015. Landasan Psikologi Proses Pendidikan. Bandung: PT Remaja Rosdakarya.

Suryosubroto H. 1990. Beberapa Aspek Dasar-Dasar Kependidikan, Jakarta: Rineka Cipta.

Syah Muhibbin. 2009. Psikologi Belajar. Jakarta: PT Raja Grapindo Persada.

Syatra Nuni Yusvavera. 2013. Desain Relasi Efektif Guru dan Murid. Jogjakarta: Buku Biru.

Slameto. 2013. Belajar dan Faktor-Faktor yang Mempengaruhinya. Jakarta: PT Rineka Cipta. 


\section{6 | Fitriani}

Sanjaya H. Wina. 2009. Penelitian Tindakan Kelas. Kencana: Prenada Media Grup.

S Syamsu. 2017. Strategi Pembelajaran. Makassar: CV Nas Media Pustaka.

Sarwono W.Wirawan. 2012. Pengantar Psikologi Umum. Jakarta: PT Raja Grafindo.

Tarigan Guntur Henry. 1979. Membaca Sebagai Suatu Keterampilan Berbahasa. Bandung: Angkasa.

Thaha, H., \& Rustan, E. (2017). Orientasi Religiusitas dan Efikasi Diri dalam Hubungannya dengan Kebermaknaan Pendidikan Agama Islam pada Mahasiswa IAIN Palopo. Studi Agama Dan Masyarakat, 13(2), 163-179. https:/ / doi.org/ 10.23971/jsam.v13i2.551

Utami Faizah Dewi. 2003. Belajar Mengajar yang Menyenangkan. Solo: PT Tiga Serangkai Pustaka Mandiri.

Yamin Moh. 2009. Manajemen Kurikulum Pendidikan. Jogjakarta: Diva Press.

Zulela. 2012. Pembelajaran Bahasa Indonesia. Bandung: PT Remaja Rosdakarya Offset. 